\title{
DEVELOPMENT OF HYMENAEA COURBARIL SEEDLINGS IN FUNCTION OF CONTAINERS AND IRRIGATION BLADES ${ }^{1}$
}

\author{
César Antônio da Silva ${ }^{2 *}$, Durval Dourado $\mathrm{Neto}^{3}$, Cícero José da Silva ${ }^{4}$ and Carlos Alessandro de Freitas ${ }^{5}$ \\ ${ }^{1}$ Received on 15.02.2012 accepted for publication on 23.03.2016. \\ ${ }^{2}$ Universidade de São Paulo, Departamento de Engenharia de Biossistemas, Programa de Pós-Graduação em Irrigação e Drenagem, \\ Piracicaba, SP - Brasil. E-mail: <cesarsilva@usp.br>. \\ ${ }^{3}$ Universidade de São Paulo, Departamento de Produção Vegetal, Piracicaba, SP - Brasil. E-mail: <ddourado@usp.br>. \\ ${ }^{4}$ Instituto Federal Goiano, Campus Morrinhos, Departamento de Agronomia, Morrinhos, GO - Brasil. E-mail: \\ <cicero.silva@ifgoiano.edu.br>. \\ ${ }^{5}$ Instituto Federal Goiano, Campus Urutaí, Graduando em Bacharelado em Agronomia, Urutaí, GO - Brasil. E-mail: \\ $<$ carloscaf77@gmail.com>. \\ *Corresponding author.
}

\begin{abstract}
The objective of this work was to evaluate the effect of container sizes and irrigation levels on "jatoba" (Hymenaea courbaril L.) seedlings development. The experiment was conducted in a greenhouse from September 2010 to March 2011. The design was in randomized blocks, with three replications in split plots, in a 2 x 5 scheme. Two container sizes (rigid pots of $3.1 \mathrm{~L}$ and stiff plastic tubes of $4.0 \mathrm{~L})$ were used in the plots, while five drip irrigation levels $(20 \%, 40 \%, 60 \% 80 \%$ and $100 \%$ of potential evapotranspiration - ETp) were used in the subplots. The irrigations were accomplished daily. Each subplot was constituted by eight seedlings. In the period from 80 to 200 days after sowing (DAS), the seedling height (AM), stem diameter (DC), leaves number (NF), leaf area (AF), dry matter mass of roots (MSR) and seedling (MSM) and relation between root dry matter mass and aerial part (MSR/ MSPA) were evaluated. The stiff plastic tube provided larger ETp, in comparison with the rigid pot and, consequently, more developed seedlings. Irrigation levels from $90 \%$ to $100 \%$ of ETp provided more vigorous seedlings. The increase of water deficit reduces all the parameters of jatoba seedlings, except the MSR/MSPA ratio.
\end{abstract}

Keywords: Hymenaea courbaril L.; Potential evapotranspiration; Water deficit

\section{DESENVOLVIMENTO DE MUDAS DE JATOBAZEIRO EM FUNÇÃO DE RECIPIENTES E LAMINAS DE IRRIGAÇÃO}

\begin{abstract}
RESUMO - O objetivo deste trabalho foi avaliar o efeito de lâminas de irrigação e tamanhos de recipiente no desenvolvimento de mudas de jatobazeiro (Hymenaea courbaril L.). O experimento foi conduzido em casa de vegetação, no período de setembro de 2010 a março de 2011. O delineamento foi o de blocos ao acaso, com três repetições, em parcelas subdivididas, no esquema $2 \times 5$. Nas parcelas, utilizaramse dois tamanhos de recipientes (vaso rígido de 3,1 L e citrovaso ${ }^{\circledR}$ reto de 4,0 L) e, nas subparcelas, cinco lâminas de irrigação $(20 \%, 40 \%, 60 \%, 80 \%$ e $100 \%$ da evapotranspiração potencial - ETp) por gotejamento, aplicadas diariamente. Cada subparcela foi constituída por oito mudas. No período de 80 a 200 dias após a semeadura (DAS), foram avaliados a altura de muda (AM), diâmetro de caule (DC), número de folhas, área foliar (AF), massas de matéria seca de raízes (MSR) e de muda (MSM) e relação entre as massas de matéria seca de raizes e parte aérea (MSR/MSPA). O citrovaso proporcionou maior ETp, em relação ao vaso e, consequentemente, mudas mais desenvolvidas. Lâminas com $90 \%$ a 100\% da ETp propiciaram mudas de jatobazeiro mais vigorosas. O aumento do deficit hídrico reduziu todos os parâmetros morfológicos avaliados das mudas de jatobazeiro, exceto a relação MSR/MSPA.
\end{abstract}

Palavras-chave: Hymenaea courbaril L.; Evapotranspiração potencial; Déficit hídrico. 


\section{INTRODUCTION}

The deforestation and the consequent need for recovery of degraded areas, have increased in Brazil the interest for the planting of native species, among them, the jatobazeiro (Hymenaea courbaril L.). The jatobazeiro is a semideciduous tree, from Fabaceae family, that naturally occurs in several Brazilian biomes, since the Piauí until the north of Paraná, may reach 10 to $15 \mathrm{~m}$ in height (CARVALHO FILHO et al., 2003), or up to $30 \mathrm{~m}$, in the Amazon (NASCIMENTO, 2009).

Their wood is highly resistant, quite marketed and used in civil construction. The starch pulp of the fruits is rich in nutrients and used in human food, whether "in natura", or in the form of cakes, bread, jam, liquor and porridges and may the flour of the jatoba partially replace wheat flour(SILVAetal., 2001). Given its importance in the timber and food sectors, information is necessary on potential evapotranspiration of $H$. courbaril in containers of different sizes, for an appropriate management of irrigation in seedlings of this species.

With relation to the container, the higher the volume, the greater is the need for space in the nursery and the cost with the substrate, labor, benches, transport and distribution of the seedlings in the field. However, small containers can cause damage to the development of the seedlings, both in the nursery phase, and after transplanting. Neves et al. (2005) concluded that the volume of the container has influenced the quantity of roots and the architecture of the root system of acacia-black (Acacia mearnsii) in the field because some containers have induced the development of curved shapes roots. Samôr et al. (2002), to discuss the effect of receptacles in angico seedlings (Anadenanthera macrocarpa), affirm that, with the seedlings in stress conditions, it tends to occur allocation increase of photoassimilated to the roots, to the detriment of the aerial part.

Nurseymen generally use tubes for the production of seedlings of species of the genera Pinus e Eucalyptus. However, species as $H$. courbaril require larger containers, due to the size of its seeds, in addition to the longer time required for staying of the seedlings in the nursery. Carvalho Filho et al. (2003), experiencing two environments (A), four substrates (S) and two sizes of vases (R) on growth of seedlings of $H$. courbaril, verified significant interaction between $A$ and $R$ at the height of the seedlings (AM), between $\mathrm{R}$ and $\mathrm{S}$ in the diameter of the stem (DC) and mass of root dry matter (MSPA) and, between A, S and R in DC. At 180 days after sowing, the AM was greater in the container of greater volume (polyethylene bag $(15 \times 20 \mathrm{~cm})$ under netted shade. The MSPA was also greater in this container filled with soil + sand $1: 1$ or soil + sand + cattle manure (1:2:1, as well as the DC, when you put it under netted shade, using soil + sand $1: 1$.

Ferraz and Engel (2011) verified that containers of less volume reduce quality of seedlings of $\mathrm{H}$. courbaril. They concluded that vials of greater volume $\left(300 \mathrm{~cm}^{3}\right)$ showed seedlings with height and diameter of the superior lap to those produced in tubes of 50 and $110 \mathrm{~cm}^{3}$, enabling to reduce time to production of seedlings in up to 70 days.

With relation to irrigation, water is essential in the processes of absorption, sap flow, transpiration and turgidity (SANTOS; CARLESSO, 1998). The stomatic closing, the reduction of perspiration and leaf area are prominent responses of plants to water deficit (FIGUEIRÔA et al., 2004; PEREIRA et al., 2006). Both the deficit and the water excess are harmful to plants, depending on its intensity and duration. Leles et al. (1998) experienced three water regimes (daily irrigation, every seven days and every 15 days) in the production of seedlings of $H$. courbaril, elevating the moisture of the substrate to the "field capacity" after each scheme. They verified that, to the 110 days after seeding, the irrigation every seven days increased significantly the MSR, 1.13 to $1.80 \mathrm{~g} \mathrm{seedling}^{-1}$, in relation to daily irrigation. However, there was no significant difference on the height, stem diameter and dry matter of the aerial part of the seedlings in the two schemes.

The appropriate management of irrigation acquires a significant importance, because the water deficit can cause the decrease in the nutrients absorption, while the excess favors the leaching of nutrients and enhances favorable microclimate to the development of diseases, in addition to increasing the consumption of water, energy and fertilizers (Lopes et al., 2005).

Lee and Langenheim (1975) affirm that H. courbaril is undemanding in soil moisture, however, Nascimento et al. (2011) concluded that the production of dry matter of seedlings of this species is the most sensitive variable to water deficiency, being necessary other experimental research for better research of water needs of that species. The latter verified that humidity levels below $50 \%$ of 
the retention capacity of the soil, in the period of 50 to 155 days after germination, substantially restrict the height, number of leaves, diameter of the stem and leaf area of the seedlings. Containers of different sizes can present distinct evapotranspirometric demands and, consequently, greater or lesser need for irrigation, in reason of the height, volume of substrate and evaporative area being different.

Thus, the objective of this work was to evaluate the development of seedlings of H. courbaril L. in function of container sizes and blades of irrigation, in vegetation house.

\section{MATERIALAND METHODS}

The experiment was conducted in the period from September 2010 to March 2011, on benches, in vegetation house, under the conditions of temperature and relative humidity indicated in Figure $1\left(22^{\circ} 42^{\prime} 41^{\prime \prime S}\right.$ and $47^{\circ} 37^{\prime} 46^{\prime \prime} \mathrm{W}, 561 \mathrm{~m}$ of altitude), installed in the east-west direction, in the Engineering Department of Biosystems College of Agriculture "Luiz de Queiroz", in Piracicaba, SP.

The substrate used was a mixture of $50 \%$ of commercial substrate and $50 \%$ of fine sand air dried, volume-based, whose physical and chemical analyzes are presented in Table 1 . For every $100 \mathrm{~L}$ of the mixture $15 \mathrm{~L}$ of vermiculite and $200 \mathrm{~g}$ of fertilizer 20-11-15
$\left(\mathrm{N}-\mathrm{P}_{2} \mathrm{O}_{5}-\mathrm{K}_{2} \mathrm{O}\right)$ were added, also composed of micronutrients $(0.2 \% \mathrm{Fe} ; 0.1 \% \mathrm{Zn} ; 0.05 \%$ of $\mathrm{B}$, of $\mathrm{Mn}$ and $\mathrm{Cu} ; 0.005 \%$ of $\mathrm{Co}$ and $\mathrm{Mo}$ ).

Seeds of jatobazeiro were obtained from four parent trees in good phytosanitary conditions, in the municipality of Orizona (GO). Then, they were selected, eliminating those with flattened shape and with a mass less than $3.0 \mathrm{~g}$, being obtained a batch of 400 seeds, with a mass equal to $2325 \mathrm{~g}$. The same were mixed, scarified in metal sanding and soaked in water at room temperature for 24 hours, according to Azerêdo et al. (2003). Then, they were treated with the fungicide carbendazim $\left(150 \mathrm{~g} \mathrm{~L}^{-1}\right)+\operatorname{Thiram}^{\circledR}\left(350 \mathrm{~g} \mathrm{~L}^{-1}\right)$, at a dose of $6.0 \mathrm{~mL}$ of the commercial product per $\mathrm{kg}$ of seed. Sowing was performed in $300 \mathrm{~mL}$ plastic cups, perforated in the base and filled with the mixture.

At 30 days after sowing (DAS), seedlings of uniform development, with the first pair of leaves open, were transplanted to receptacles. The experimental design was randomized blocks, with three repetitions, the split plot scheme $2 \times 5$. In the plots, two sizes of vases were used (rigid bottle of $3.1 \mathrm{~L}$ and citrovase $\AA$ rectus of 4.0 L, container aimed especially for the production of citrus seedlings) and at the plots, five irrigations slides $(20 \%, 40 \%, 60 \%, 80 \%$ and $100 \%$ of the daily evapotranspiration potential - ETp). Each subplot consisted of eight seedlings, totaling 240 . The vases

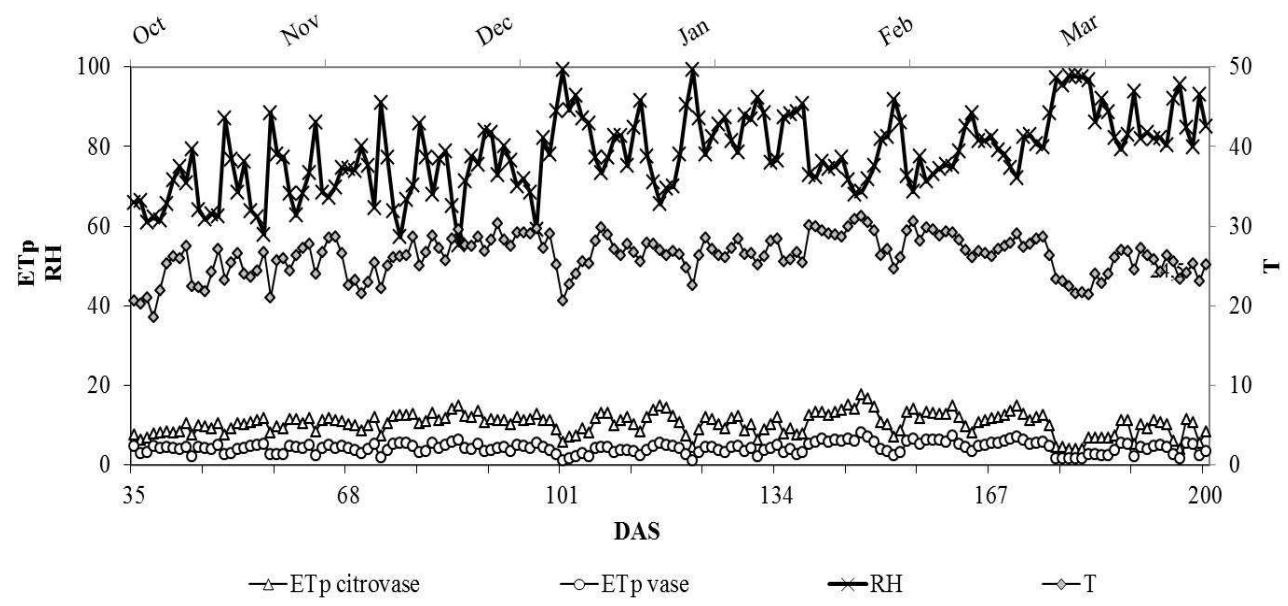

Figure 1 - Average daily of temperature $\left(\mathrm{T},{ }^{\circ} \mathrm{C}\right)$, relative humidity $(\mathrm{RH}, \%)$ and potential evapotranspiration $(\mathrm{ETp}, \mathrm{mm}$ $\mathrm{dia}^{-1}$ ) of jatoba seedling, in function of containers, in the period from 35 to 200 days after sowing (DAS), in greenhouse, in Piracicaba, SP.

Figura 1 - Valores médios diários de temperatura $\left(T,{ }^{\circ} \mathrm{C}\right)$, umidade relativa do ar (UR, \%) e evapotranspiração potencial (ETp, $\mathrm{mm} \mathrm{dia}^{-1}$ ) de mudas de jatobazeiro, em função dos recipientes, no periodo de 35 a 200 dias após a semeadura (DAS), em casa de vegetação, em Piracicaba, SP. 
Table 1 - Results of physical and chemical analysis of the commercial substrate and fine sand mixture.

Tabela 1 -Resultados de análises físicas e químicas 1 da mistura de substrato comercial e areia fina.

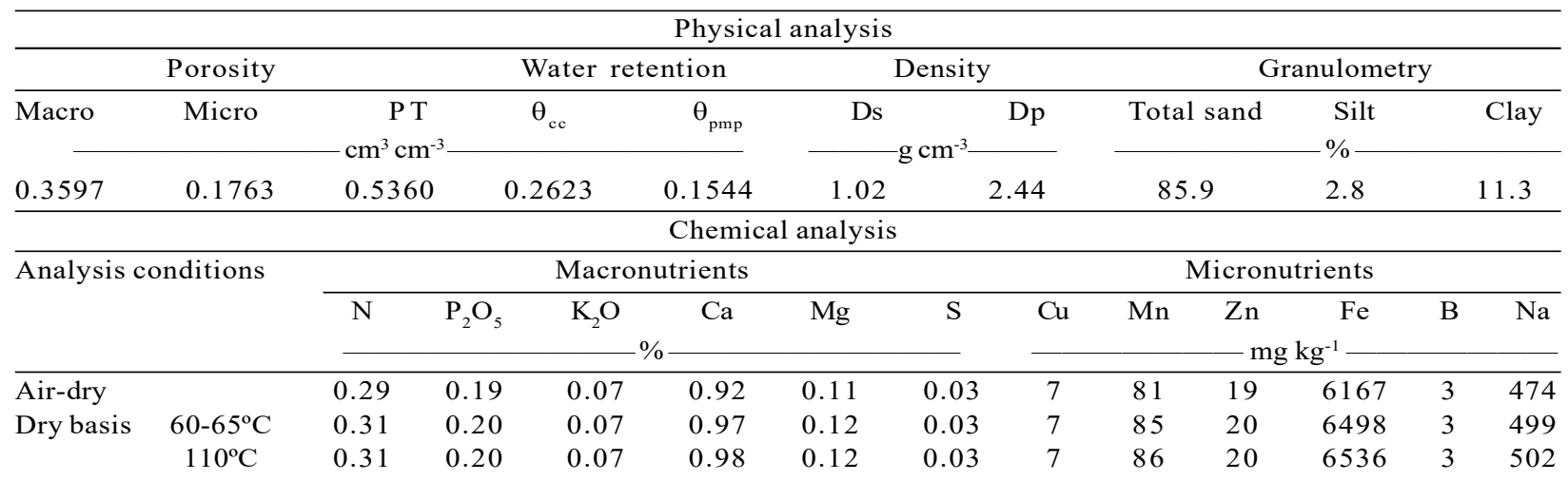

${ }^{1}$ Analyzes performed in the Laboratory of the Department of Soil Science, ESALQ/USP. PT, total porosity; $\theta$, humidity in the "field capacity", volume-based; $\theta_{\text {pmp }}$, humidity of permanent wilting point; DS, density of the substrate; Dp, particle density of the substrate.

exhibited $19.0 \mathrm{~cm}$ in diameter in the top edge, $15.0 \mathrm{~cm}$ of diameter at the base and $15.0 \mathrm{~cm}$ of height, while citrovases measured $14.0 \mathrm{~cm}$ of superior diameter, 10.2 $\mathrm{cm}$ of diameter at the base and $35.5 \mathrm{~cm}$ high. The containers were made of polypropylene, with eight holes in the base. The seedlings were distributed on the benches in four lines, each with 60 seedlings, according to the direction of the side lines of the irrigation system.

It was used the system by dropping, with selfcompensating sprinklers, flow rate equal to 2.0 and $4.0 \mathrm{~L} \mathrm{~h}^{-1}$, in different adapters combinations for 2 and 4 outputs, to obtain adequate flow $(0.5 ; 1.0 ; 1.5 ; 2.0$ and $2.5 \mathrm{~L} \mathrm{~h}^{-1}$ ) equivalent to blades with the irrigation time equal in all the treatments of the same container. The blades were applied daily irrigation, having begun at $35 \mathrm{DAS}$. The potential evapotranspiration rate of seedlings (ETP), in $\mathrm{mm}$, and the irrigation time (TI), in seconds, were determined according to the equations:

$$
\begin{aligned}
& \mathrm{ETp}=\frac{40 \cdot \mathrm{M}_{\theta \mathrm{cc}}-\mathrm{M}_{\theta \text { current }}}{\rho \cdot \pi \cdot \mathrm{D}^{2}} \\
& \mathrm{Ti}=\frac{360 \cdot \mathrm{ETp} \cdot \mathrm{A}_{\text {contcincr }}}{1000 \cdot \mathrm{q}}
\end{aligned}
$$

Where: $\mathrm{M} \theta_{\mathrm{cc}}$ is the mass of container + seedlings + substrate on the moisture of the field capacity $(\mathrm{g})$; $\mathrm{M} \theta_{\text {current }}$ is the mass of the container + seedlings + substrate on current moisture $(\mathrm{g}) ; \rho$ is the specific mass of water at room temperature (approximately 1.0 $\left.\mathrm{g} \mathrm{cm}^{-3}\right)$; $\mathrm{D}$ is the diameter of the upper edge of the container $(\mathrm{cm})$, and $\mathrm{A}_{\text {container }}$ is the container area $\left(\mathrm{cm}^{2}\right)$, both at the level of the substrate, and $q$ is the flow rate of the container $\left(\mathrm{L} \mathrm{h}^{-1}\right)$.

The difference in mass ( $\left.\mathrm{M} \theta_{\mathrm{cc}}-\mathrm{M} \theta_{\text {current }}\right)$ of three containers of each type was measured daily, by means of digital scale with capacity of $10,000 \mathrm{~g}$ and precision of $1.0 \mathrm{~g}$. After weighing, the refitting of the mass of water lost through evapotranspiration was done, returning the substrate to $\theta_{\mathrm{cc}}$.

The fertilization in the substrate consisted of applying, per seedlings, $1.0 \mathrm{~g}$ of ammonium sulfate, 45 and 140 DAS, and 1.0 g of fertilizer 20-11-15+ micronutrients, at $75 \mathrm{DAS}$, based on the chemical analysis of the substrate and the work of Pacheco (2008), on soil fertilization in seedlings of Dipteryx alata Vog., this species of the same botanical family of jatobazeiro. The calcium and part of sulfur and copper were supplied via leaf fertilization, through spray Bordeaux mixture to 30 and $120 \mathrm{DAS}$. The syrup was prepared in the proportion of $1.0 \mathrm{~L}$ of water, $4.0 \mathrm{~g}$ virgin lime and 4.0 $\mathrm{g}$ of copper sulphate. Any weeds were manually eliminated.

During the experimental period, the temperature and the relative humidity of the air were registered in datalogger, inside the protected environment. In the period from 80 to 200 days after sowing (DAS), four evaluations of height of seedlings (AM), diameter of the stem (DC) and number of leaves (NF), and three, leaf area (AF), masses of dry matter of roots (MSR) and of seedlings (MSM) were carried out, obtained by the sum of the MSR with the dry matter of the aerial part (MSPA), and the ratio MSR/ADM. The AF was 
determined by the method of the mass of leaf rectangles, according to Gondim et al. (2009).

\section{RESULTS}

The potential evapotranspiration (ETp) of jatobazeiro was greater in seedlings produced in citrovase regarding the vases, throughout the experimental period (Figure 1). The ETp was superior both in terms of daily (mm blade day $\left.^{-1}\right)$ and in terms of mass $\left(\mathrm{g} \mathrm{day}^{-1}\right)$ of evaportranspired water, despite of presenting lower citrovase evaporative area $\left(153.9 \mathrm{~cm}^{2}\right)$ than the vases $\left(283.5 \mathrm{~cm}^{2}\right)$.

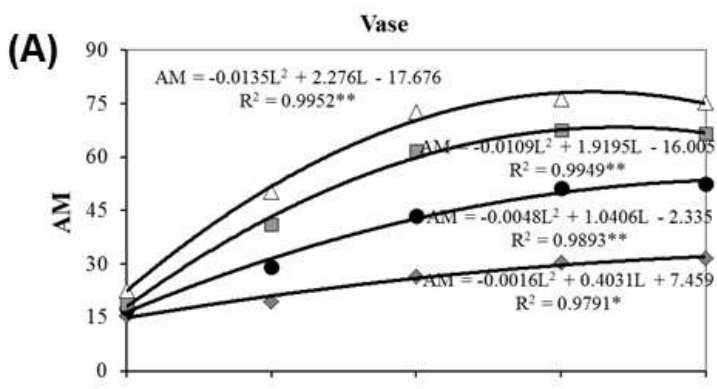

(B)

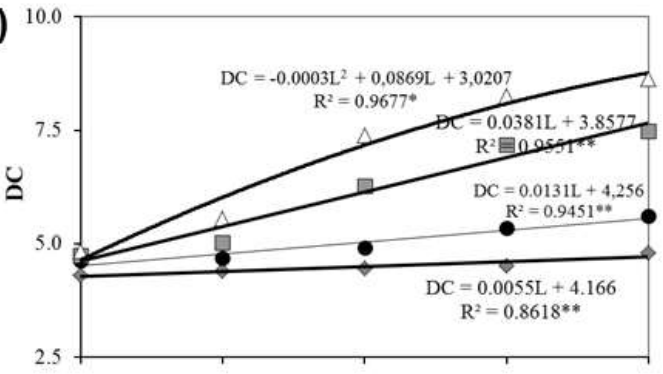

(C)

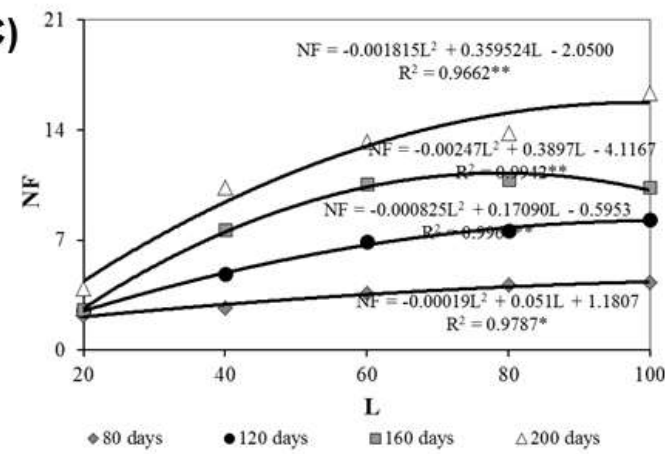

The largest ETp based on earth, in citrovase, is, in part, due to a greater volume of that container $(4.0 \mathrm{~L})$ in relation to the vases $(3.1 \mathrm{~L})$, since the greatest mass of substrate in the first, heated by the solar global radiation energy, presented daily larger differences of weighing and, consequently, greater ETp.

The types of containers had significant effects $(p<0.05)$ or highly significant $(p<0.01)$ over the seedling height and number of leaves, to 80, 120, 160 and 200 days after sowing (DAS), the diameter of the stem (DC) to 160 and 200 of the mass, leaf area, dry matter of
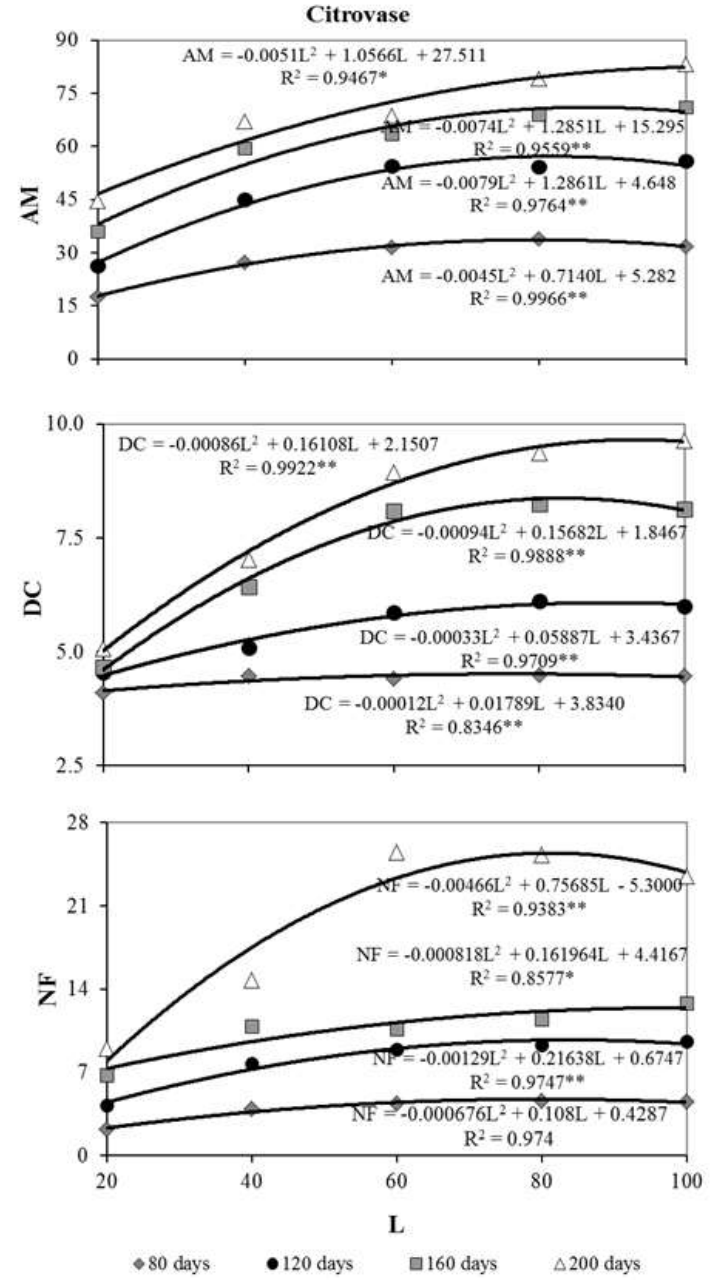

Figure 2 - Seedling height (AM, cm), stem diameter (DC, mm) and leaves number (NF) of jatoba seedlings in function of containers, irrigation levels (L, \% ETp) and days after the sowing, grown under greenhouse.

Figura 2 - Altura de muda (AM, cm), diâmetro de caule (DC, mm) e número de folhas (NF) do jatobazeiro em função de recipientes, lâminas de irrigação (L, \% ETp) e dias após a semeadura, em casa de vegetação.

Revista Árvore, Viçosa-MG, v.40, n.3, p.487-498, 2016 
roots and dry matter mass of seedlings, to 120,160 and 200 days and the ratio of the masses of dry matter of roots and aerial part (MSR/MSPA), to 120 of, the $5 \%$ probability, by $\mathrm{F}$ test.

The irrigation blades influenced all the morphological parameters of the seedlings of jatobazeiro (AM, DC, $\mathrm{NF}, \mathrm{AF}, \mathrm{MSR}$ and MSM), regardless of age. All parameters were highly significant $(p<0.01)$, being significant $(p<0.05)$ the relationship MSR/MSPA TO 120 DAS. There was significant interaction between the type of container and blades for all parameters evaluated, with the exception of AF, at 160 and 200 days.

In the vases, the seedlings under irrigation blade $100 \%$ of the ETp, presented AM 31.6; 52.6; 66.6 and $75.5 \mathrm{~cm}$, to $80,120,160$ and 200 of, respectively, while in citrovase, the heights were $31.8 ; 55.9 ; 71.0$ and 83.2 $\mathrm{cm}$, these same ages (Table 2). At 200 DAS, the AM under the blade of $100 \%$, in vase and citrovase, was 3.3 and 1.9 times, respectively, greater than in relation to blade $20 \%$. The largest growth of AM occurred in phase of 80 to 120 of, in citrovases, in the absence of water restriction.

With relation to DC, higher values were observed in the blades of 80 and $100 \%$ of the ETp, on both the containers, reaching maximum values of 8.64 and 9.64 $\mathrm{mm}$, in the vase and in citrovase, respectively, to 200 of(Figure 2B and Table 2). In both containers, the greatest growth of DC, took place in phase of 120 to 160 of irrigation on blades equivalent to 60,80 and $100 \%$ of the ETp. Between the first ( $4.64 \mathrm{~cm}$ to $80 \mathrm{of}$ ) and the last evaluation ( $9.14 \mathrm{~cm}$ to $200 \mathrm{DAS})$, the average growth of DC (vase and citrovase) was approximately $97 \%$, in the absence of water restriction (100\% of irrigation blade), while in condition of extreme deficit $(20 \%$ of the ETp), the growth was only $17.8 \%$ (4.96 - 4.21/4.21 $\mathrm{x}$ 100).

Larger number of leaves (NF) and leaf area (AF) were observed in the period of 160200 DAS, especially in blades of 80 and $100 \%$ of the ETp, applied in citrovases. The maximum number of sheets observed was 16 and 23, respectively, in the vase and in citrovase, in seedlings with 200 DAS, submitted to refitting of $100 \%$ of the ETp, while in the most severe water deficit $20 \%$ ) blade, these values were 4 and 9 sheets (Figure $2 \mathrm{C})$. In vases under the blade of $60 \%$, the $\mathrm{AF}$ increased by $3.34(1582.8 / 472.6)$ times in the last 80 days of the experiment (120 to 200). The greatest increase of AF after $120 \mathrm{DAS}$, on both the containers, is due to, in part, the stage of development of jatobazeiro seedlings, and partly to the greater evapotranspiration, by reason of the greater weight of roots dry matter.

Up to $120 \mathrm{DAS}$, the seedlings in vases presented AF increased linearly in function of the irrigation blades. The AF maximum observed in this container, to 120 DAS, was $705.0 \mathrm{~cm}^{2}$ seedling ${ }^{-1}$, while the jatobazeiros in citrovase presented in this same age, maximum AF $859.4 \mathrm{~cm}^{2}$ seedling ${ }^{-1}$, under irrigation blade of $80 \%$ of the ETp (Figure $3 \mathrm{~A})$.

At 160 and 200 DAS, AF showed no significant interaction between containers and irrigation blades. The great blades in their respective ages, were estimated in $92.0 \%$ and $89.5 \%$ of the ETp, which result from AF maximum 1489.2 and $2104.6 \mathrm{~cm}^{2}$ seedling ${ }^{-1}$, regardless of the container. The most severe water deficit compromised considerably the AF, in both the recipients. It was observed wilting symptoms in seedlings irrigated to $20 \%$ of the ETp, mainly in the period from 11:00 am to 05:00 pm, in sunny days, and recovery of its turgidity at night after the irrigation.

The mass of dry matter of roots (MSR) in vases, at $120 \mathrm{DAS}$, showed linear response in function of the irrigation blades (Figure 3B) At 160 and 200 DAS the equation of $3 \mathrm{rd}$ degree showed a better adjustment to the data of the MSR within these containers, being the maximum of $11.9 \mathrm{~g} \mathrm{MSR} \mathrm{seedlings}^{-1}$, estimated with blade of $92.0 \%$, at 200 days. In the last 80 days of the experiment, the greatest increment of MSR within these containers was of $9.68 \mathrm{~g}$ seedlings $^{-1}$, this increase being observed in the blades of $80 \%$ and $100 \%$. Now, with relation to citrovase, $120 \mathrm{DAS}$, the largest MSR was $3.2 \mathrm{~g}$ seedling $^{-1}$, at the absence of water deficit, while in the following stages, the great irrigation blades varied from $90.1 \%$ (160 DAS) to $88.8 \%$ (200 DAS), when the MSR achieved the value of $15.2 \mathrm{~g} \mathrm{seedling}^{-1}$.

The mass of seedlings dry matter (MSM) of jatobazeiro considerably reduced with the increase of water deficit, being all organs (roots, stems and leaves) affected. In the container of lower volume (vase), the levels of irrigation had increasing linear effect on the MSM, until 120 DAS; however, the equations of $2^{\text {nd }}$ and $3^{\text {rd }}$ degrees were significant at 160 and 200 DAS. At 200 DAS, the maximum production of MSM in this container was estimated at $34.0 \mathrm{~g}$ seedling $^{-1}$, with the blade of $93.0 \%$ of the ETp (Figure 3C). 
Development of hymenaea courbaril...

Table 2 - Seedling height, stem diameter, leaves number, leaf area, roots dry matter mass, seedling dry matter mass and ratio of dry matter masses of roots and aerial part (MSR/MSPA) of jatoba seedlings, in function of age, containers and irrigation levels, in greenhouse.

Tabela 2 - Altura de muda, diâmetro de caule, número de folhas, área foliar, massa de matéria seca de raízes e de muda e, relação das massas de matéria seca de raizes e parte aérea (MSR/MSPA) do jatobazeiro, em função da idade, recipientes e lâminas de irrigação, em casa de vegetação.

\begin{tabular}{|c|c|c|c|c|c|c|c|c|c|}
\hline \multirow{2}{*}{$\begin{array}{l}\text { Evaluated } \\
\text { characteristic }\end{array}$} & \multirow[t]{2}{*}{ Age (days) } & \multirow[t]{2}{*}{ Recipient } & \multicolumn{5}{|c|}{ Irrigation blade (\% ETp) } & \multirow[t]{2}{*}{ Average } & \multirow[t]{2}{*}{ DMS } \\
\hline & & & 20 & 40 & 60 & 80 & 100 & & \\
\hline \multirow{12}{*}{$\begin{array}{l}\text { Seedling } \\
\text { height }(\mathrm{cm})\end{array}$} & \multirow[t]{3}{*}{80} & Citrovase & $17.59 \mathrm{a}$ & $27.18 \mathrm{a}$ & $31.46 \mathrm{a}$ & $33.80 \mathrm{a}$ & $31.79 \mathrm{a}$ & 28.36 & 2.46 \\
\hline & & Vase & $15.58 \mathrm{a}$ & $19.54 \mathrm{~b}$ & $26.53 \mathrm{~b}$ & $30.51 \mathrm{~b}$ & $31.59 \mathrm{a}$ & 24.75 & \\
\hline & & Average: & 16.58 & 23.36 & 29.00 & 32.15 & 31.69 & 26.56 & \\
\hline & \multirow[t]{3}{*}{120} & Citrovase & $26.26 \mathrm{a}$ & $45.10 \mathrm{a}$ & $54.48 \mathrm{a}$ & $54.26 \mathrm{a}$ & $55.86 \mathrm{a}$ & 47.19 & 4.76 \\
\hline & & Vase & $17.60 \mathrm{~b}$ & $29.20 \mathrm{~b}$ & $43.47 \mathrm{~b}$ & $51.37 \mathrm{a}$ & $52.64 \mathrm{a}$ & 38.86 & \\
\hline & & Average: & 21.93 & 37.15 & 48.98 & 52.82 & 54.25 & 43.02 & \\
\hline & \multirow[t]{3}{*}{160} & Citrovase & $36.07 \mathrm{a}$ & 59.49 a & $63.63 \mathrm{a}$ & $68.91 \mathrm{a}$ & $71.04 \mathrm{a}$ & 59.83 & 6.24 \\
\hline & & Vase & $18.84 \mathrm{~b}$ & $41.06 \mathrm{~b}$ & $61.68 \mathrm{a}$ & $67.51 \mathrm{a}$ & $66.56 \mathrm{a}$ & 51.13 & \\
\hline & & Average: & 27.45 & 50.28 & 62.66 & 68.21 & 68.80 & 55.48 & \\
\hline & \multirow[t]{3}{*}{200} & Citrovase & $44.57 \mathrm{a}$ & $67.03 \mathrm{a}$ & $68.80 \mathrm{a}$ & $79.30 \mathrm{a}$ & $83.19 \mathrm{a}$ & 68.58 & 9.84 \\
\hline & & Vase & $22.74 \mathrm{~b}$ & $50.42 \mathrm{~b}$ & $72.61 \mathrm{a}$ & $76.35 \mathrm{a}$ & $75.47 \mathrm{a}$ & 59.52 & \\
\hline & & Average: & 33.66 & 58.72 & 70.71 & 77.82 & 79.33 & 64.05 & \\
\hline \multirow{12}{*}{$\begin{array}{l}\text { Stem } \\
\text { diameter(mm) }\end{array}$} & \multirow[t]{3}{*}{80} & Citrovase & $4.10 \mathrm{~b}$ & $4.47 \mathrm{a}$ & $4.42 \mathrm{a}$ & $4.50 \mathrm{a}$ & $4.47 \mathrm{~b}$ & 4.39 & 0.18 \\
\hline & & Vase & $4.31 \mathrm{a}$ & $4.40 \mathrm{a}$ & $4.46 \mathrm{a}$ & $4.51 \mathrm{a}$ & $4.80 \mathrm{a}$ & 4.50 & \\
\hline & & Average: & 4.21 & 4.43 & 4.44 & 4.50 & 4.64 & 4.44 & \\
\hline & \multirow[t]{3}{*}{120} & Citrovase & $4.56 \mathrm{a}$ & $5.09 \mathrm{a}$ & $5.87 \mathrm{a}$ & $6.12 \mathrm{a}$ & $5.99 \mathrm{a}$ & 5.53 & 0.27 \\
\hline & & Vase & $4.63 \mathrm{a}$ & $4.69 \mathrm{~b}$ & $4.92 \mathrm{~b}$ & $5.35 \mathrm{~b}$ & $5.61 \mathrm{~b}$ & 5.04 & \\
\hline & & Average: & 4.60 & 4.89 & 5.40 & 5.74 & 5.80 & 5.28 & \\
\hline & \multirow[t]{3}{*}{160} & Citrovase & $4.66 \mathrm{a}$ & $6.42 \mathrm{a}$ & $8.10 \mathrm{a}$ & $8.24 \mathrm{a}$ & $8.13 \mathrm{a}$ & 7.11 & 0.55 \\
\hline & & Vase & $4.75 \mathrm{a}$ & $5.02 \mathrm{~b}$ & $6.28 \mathrm{~b}$ & $7.17 \mathrm{~b}$ & $7.48 \mathrm{~b}$ & 6.14 & \\
\hline & & Average: & 4.70 & 5.72 & 7.19 & 7.71 & 7.80 & 6.63 & \\
\hline & \multirow[t]{3}{*}{200} & Citrovase & $5.08 \mathrm{a}$ & $7.02 \mathrm{a}$ & $8.95 \mathrm{a}$ & $9.37 \mathrm{a}$ & $9.64 \mathrm{a}$ & 8.01 & 0.49 \\
\hline & & Vase & $4.84 \mathrm{a}$ & $5.55 \mathrm{~b}$ & $7.40 \mathrm{~b}$ & $8.26 \mathrm{~b}$ & $8.64 \mathrm{~b}$ & 6.94 & \\
\hline & & Average: & 4.96 & 6.29 & 8.17 & 8.82 & 9.14 & 7.48 & \\
\hline \multirow{12}{*}{$\begin{array}{l}\text { Number of } \\
\text { leaves }\end{array}$} & \multirow[t]{3}{*}{80} & Citrovase & $2.21 \mathrm{a}$ & $3.92 \mathrm{a}$ & $4.38 \mathrm{a}$ & $4.63 \mathrm{a}$ & $4.55 \mathrm{a}$ & 3.94 & 0.31 \\
\hline & & Vase & $2.21 \mathrm{a}$ & $2.71 \mathrm{~b}$ & $3.63 \mathrm{~b}$ & $4.13 \mathrm{~b}$ & $4.29 \mathrm{a}$ & 3.39 & \\
\hline & & Average: & 2.21 & 3.32 & 4.00 & 4.38 & 4.42 & 3.67 & \\
\hline & \multirow[t]{3}{*}{120} & Citrovase & $4.25 \mathrm{a}$ & $7.75 \mathrm{a}$ & $8.92 \mathrm{a}$ & $9.33 \mathrm{a}$ & $9.59 \mathrm{a}$ & 7.97 & 0.50 \\
\hline & & Vase & $2.50 \mathrm{~b}$ & $4.84 \mathrm{~b}$ & $6.88 \mathrm{~b}$ & $7.63 \mathrm{~b}$ & $8.30 \mathrm{~b}$ & 6.03 & \\
\hline & & Average: & 3.38 & 6.30 & 7.90 & 8.48 & 8.94 & 7.00 & \\
\hline & \multirow[t]{3}{*}{160} & Citrovase & $6.75 \mathrm{a}$ & $10.92 \mathrm{a}$ & $10.67 \mathrm{a}$ & $11.50 \mathrm{a}$ & $12.83 \mathrm{a}$ & 10.53 & 1.51 \\
\hline & & Vase & $2.58 \mathrm{~b}$ & $7.67 \mathrm{~b}$ & $10.58 \mathrm{a}$ & $10.83 \mathrm{a}$ & $10.33 \mathrm{~b}$ & 8.40 & \\
\hline & & Average: & 4.67 & 9.29 & 10.62 & 11.17 & 11.58 & 9.47 & \\
\hline & \multirow[t]{3}{*}{200} & Citrovase & $9.00 \mathrm{a}$ & $14.75 \mathrm{a}$ & $25.50 \mathrm{a}$ & $25.33 \mathrm{a}$ & $23.50 \mathrm{a}$ & 19.62 & 2.56 \\
\hline & & Vase & $3.92 \mathrm{~b}$ & $10.33 \mathrm{~b}$ & $13.25 \mathrm{~b}$ & $13.83 \mathrm{~b}$ & $16.33 \mathrm{~b}$ & 11.53 & \\
\hline & & Average: & 6.46 & 12.54 & 19.38 & 19.58 & 19.92 & 15.58 & \\
\hline Leaf area & 120 & Citrovase & $189.0 \mathrm{a}$ & $585.9 \mathrm{a}$ & $746.1 \mathrm{a}$ & $859.4 \mathrm{a}$ & $855.8 \mathrm{a}$ & 647.2 & 78.2 \\
\hline$\left(\mathrm{cm}^{2}\right.$ seedling $\left.{ }^{-1}\right)$ & & Vase & $116.6 \mathrm{a}$ & $259.5 \mathrm{~b}$ & $472.6 \mathrm{~b}$ & $554.9 \mathrm{~b}$ & $705.0 \mathrm{~b}$ & 421.7 & \\
\hline & & Average: & 152.8 & 422.7 & 609.4 & 707.1 & 780.4 & 534.5 & \\
\hline & 160 & Citrovase & 328.8 & 1101.9 & 1443.0 & 1728.8 & 1682.7 & $1257.0 \mathrm{~A}$ & 200.5 \\
\hline & & Vase & 130.7 & 499.8 & 1064.0 & 1190.4 & 1253.8 & $827.7 \mathrm{~B}$ & \\
\hline & & Average: & 229.7 & 800.8 & 1253.5 & 1459.6 & 1468.2 & 1042.4 & \\
\hline & 200 & Citrovase & 443.2 & 1523.7 & 2012.7 & 2439.7 & 2358.8 & $1755.6 \mathrm{~A}$ & 316.1 \\
\hline & & Vase & 143.0 & 710.6 & 1582.8 & 1747.9 & 1735.2 & $1183.9 \mathrm{~B}$ & \\
\hline & & Average: & 293.1 & 1117.1 & 1797.8 & 2093.8 & 2047.0 & 1469.8 & \\
\hline
\end{tabular}


Table 2...

Tabela 2...

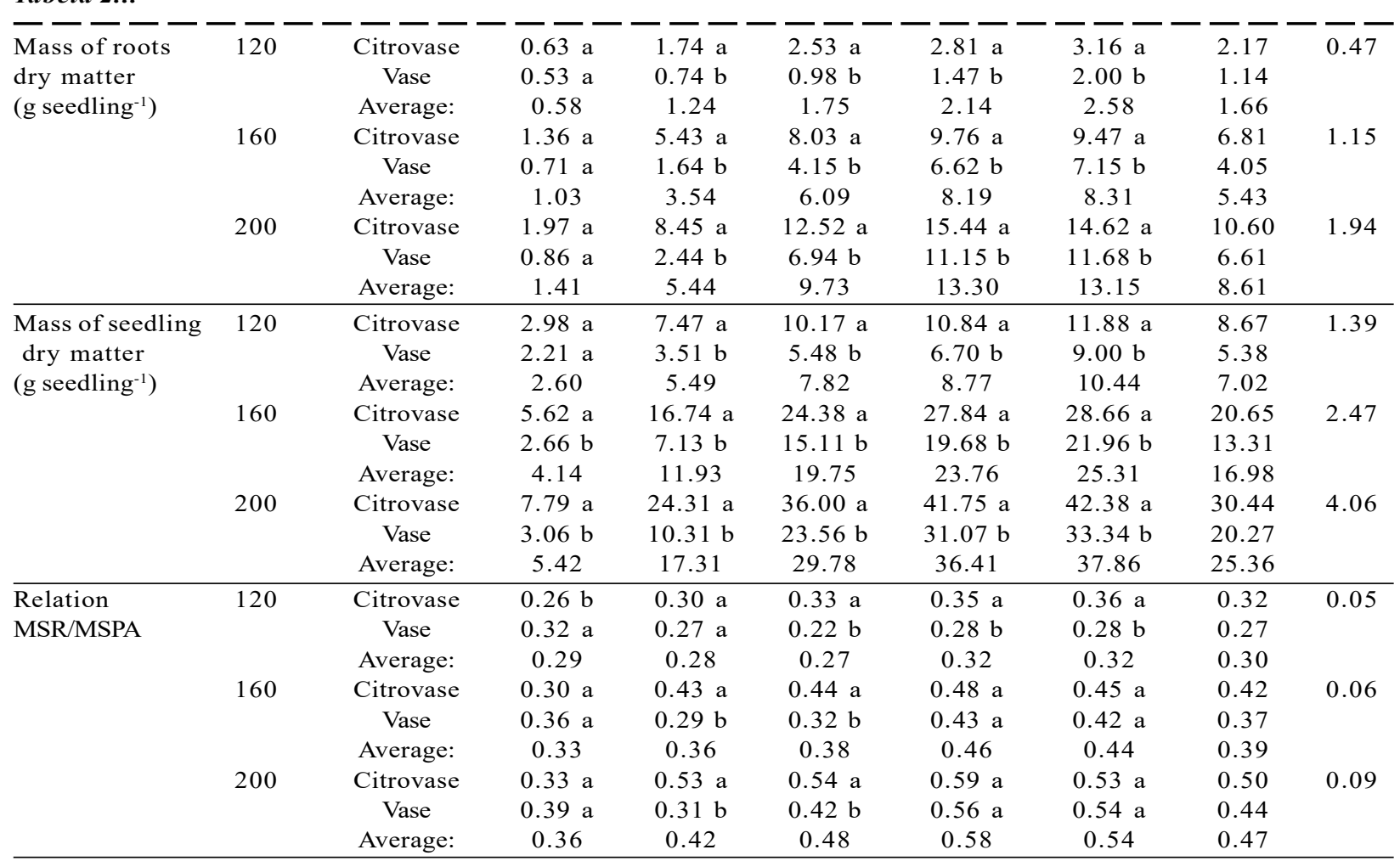

Averages followed by the same letter in column, for the same morphological parameter and age, dot not differ among themselves, by the Tukey test, at $5 \%$ probability. DMS: Minimum significant difference

In citrovase, the maximum productions of MSM were estimated in $11.7,28.8$ and 42.8 g seedling $^{-1}$, with irrigation blades of $93.4 \%, 92.4 \%$ and $92.1 \%$, at 120 , 160 and 200 DAS, respectively.

The relationship MSR/MSPA was greater in seedlings of higher age, mainly due to the increase in mass of secondary roots. Cubic equations (to 160 and 200 DAS) and 4th degree (to 120 DAS) were significant and best adjusted to the data of the MSR/ MSPA originated from the vase. Now, for the data from the citrovase, the linear equations (to $120 \mathrm{DAS}$ ) and quadratic (at 160 and $200 \mathrm{DAS}$ ) were significant at $1 \%$ (Figure 3D).

In the vase, the smaller relations MSR/MSPA were of $0.22 ; 0.28$ and 0.31 , estimated with blades of $58.2 \%$, $39.7 \%$ and $35.6 \%$ of the ETp, at 120,160 and 200 DAS, respectively. Larger blades that these have resulted in greater MSR/MSPA, however smaller blades also indicated higher MSR in detriment of the aerial part.
From 120 to 160 and from 160 to 200 DAS, there was greater increment of MSR than of MSPA, in all treatments. In citrovase, with the increase of the irrigation blades, larger volumes of humid substrate provided greater MSR, in detriment of the aerial part and, consequently, greater MSR/MSPA. The maximum value of this parameter was estimated in 0.59 , at 200 DAS with the blade of $73.3 \%$ of the ETp.

With relation to containers, it was obtained greater AM in citrovase, especially in the blades of $40 \%$ and $20 \%$ of the ETp, in the last three evaluations (Table 2). However, there was no statistical difference of AM between containers when they were irrigated at $100 \%$ of the ETp.

As for the DC, the NF and MSR, citrovase propitiated better results than the vase, in the treatments of $40 \%$ to $100 \%$ of the ETp, in the last three evaluations. However, the replacement of $20 \%$ of the ETp did not promote statistical difference of the DC between containers. 
(A)

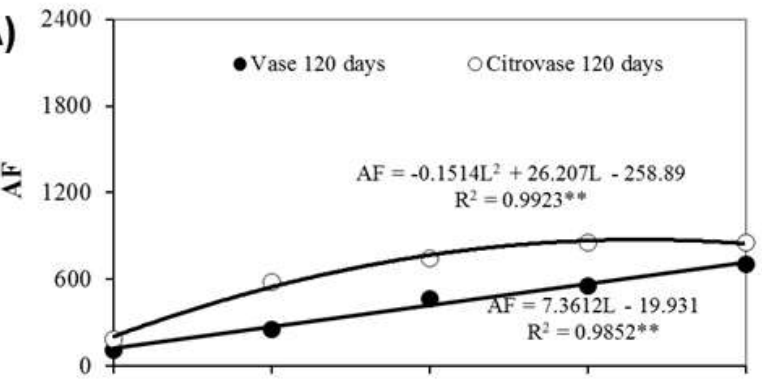

(B)

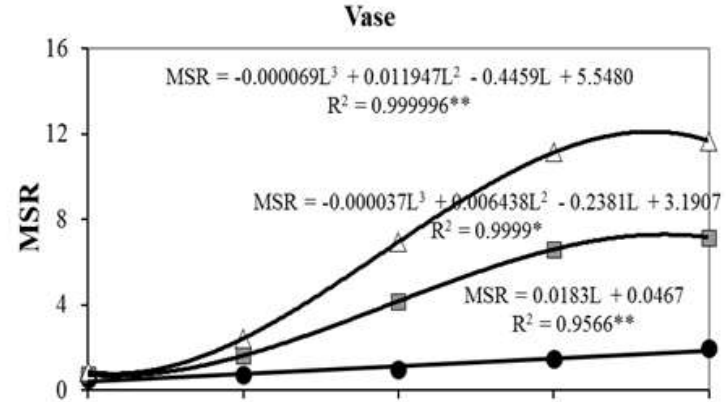

(C)

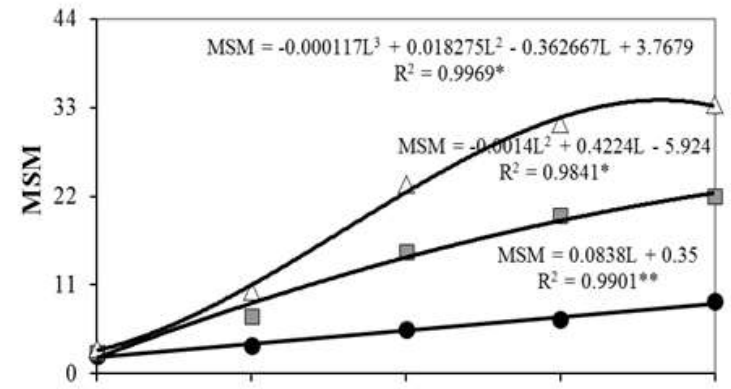

(D)

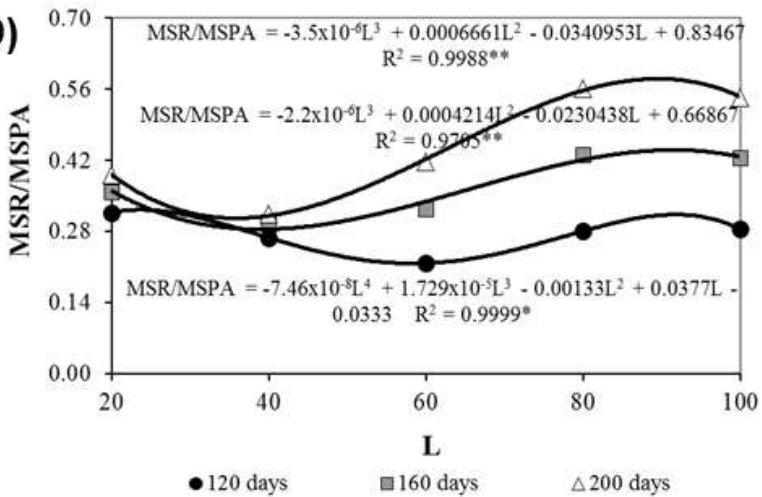

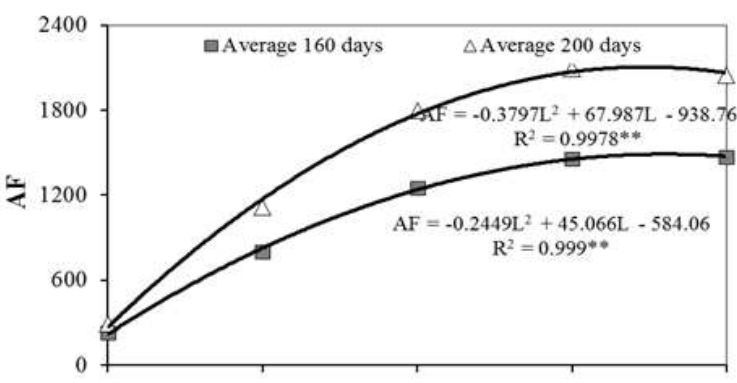

Citrovase
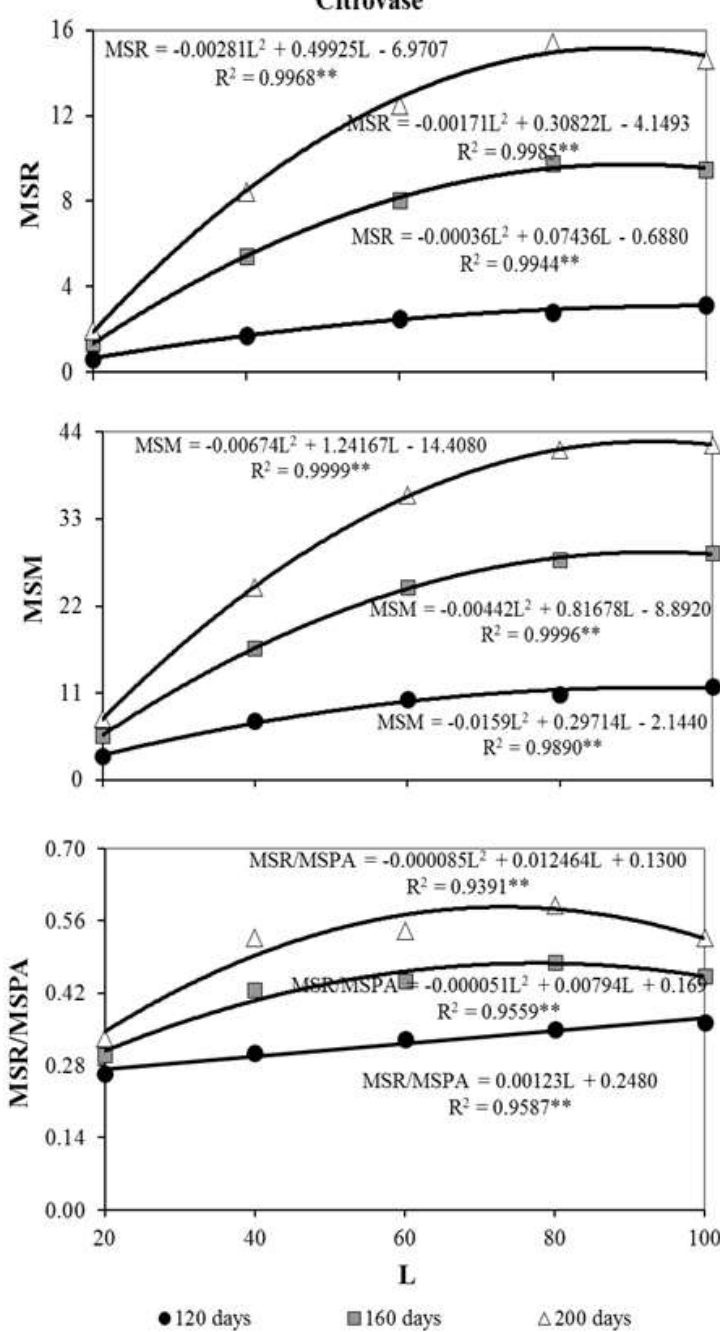

Figure 3 - Leaf area $\left(\mathrm{AF}, \mathrm{cm}^{2}\right.$ seedling ${ }^{-1}$ ), roots dry matter mass (MSR, g seedling ${ }^{-1}$ ), seedling dry matter mass (MSM, $g$ seedling ${ }^{-1}$ ) and relationship among the masses of roots and aerial part (MSR/MSPA) of jatoba seedlings, in function of containers, irrigation levels (L, \% ETp) and days after the sowing, grown under greenhouse.

Figura 3 - Área foliar $\left(A F, \mathrm{~cm}^{2}\right.$ muda $\left.{ }^{-1}\right)$, massa de matéria seca de raízes (MSR, g muda ${ }^{-1}$ ), massa de matéria seca de muda (MSM, g muda ${ }^{-1}$ ) e relação entre as massas de raízes e da parte aérea (MSR/MSPA) do jatobazeiro, em função de recipientes, lâminas de irrigação $(L, \% E T p)$ e dias após a semeadura, em casa de vegetação. 
In all levels of irrigation applied, except the $20 \%$ at $120 \mathrm{DAS}$, the AF and MSP of seedlings in citrovase was statistically superior in relation to the vase, by the Tukey test, at 5\% probability.

Jatobazeiros with four months of age, coming from citrovase, presented values of MSR/MSPA higher than those from the vase, the blades of $60 \%, 80 \%$ and $100 \%$ of the ETp, while in the blade of $20 \%$ the opposite occurred. Now, in seedlings of 160 and 200 of the citrovase was statistically superior only in the blades of $40 \%$ and $60 \%$.

\section{DISCUSSION}

Major differences between the ETp of seedlings produced in the citrovase and in the vase, were observed mainly in days of higher temperatures. It is likely that this greater difference is due to the higher leaf area and dry matter mass of roots observed in citrovase, without ignoring the possibility of greater heating of the substrate in this container, since that the contact area of the substrate with its walls $\left(1349 \mathrm{~cm}^{2}\right)$ was higher than the vase $\left(801 \mathrm{~cm}^{2}\right)$. According to Oliveira et al. (2003), for each degree Celsius increase in soil temperature (in the range of optimum growth of plants), perspiration and water absorption amounting in approximately $10 \%$, thus increasing the evapotranspiration.

In irrigation with deficit (blades of $20 \%$ and $40 \%$ ), the largest AM in citrovase, to 120, 160 and 200 DAS, is due in particular to the largest volume of humid substrate, availability of nutrients and depth reached by wetting front advance, in relation to the vase, provided that it is more adequate to the development of the root system and the absorption.

The results of AM in function of the blades, are consistent with those obtained by Nascimento et al. (2011), once these authors have obtained seedlings of $62.6 \mathrm{~cm}$ height to 155 days of age ( 105 days after the beginning of the treatments), with the irrigation blade equivalent to $100 \%$ of the "capacity of pot' (CP). Nascimento et al. (2011) verified still that seedlings submitted to $25 \%$ of $\mathrm{CP}$ had reduction of height in $42.17 \%$, in relation to the witness, this value being close to obtained at 160 DAS at this work with the blade of $20 \%$ of the ETp in citrovase, which has reduced the height in $47.8 \%$ in relation to the witness.

In condition of water deficit $(80 \%, 60 \%, 40 \%$ and $20 \%$ of the ETp), reductions of DC of jatobazeiro were similar to those obtained by Nascimento et al. (2011). At $200 \mathrm{DAS}$, the reductions of DC were $2.8 \% ; 7.2 \%$; $27.2 \%$ and $47.3 \%$, in citrovase, and $4.4 \% ; 14.4 \% ; 35.8 \%$ and $44.0 \%$, in the vase, in their respective water deficits, in relation to the witness (blade of $100 \%$ of the ETp). Nascimento et al. (2011) obtained reductions of the DC, of $16.3 \%, 20.7 \%$ and $31.0 \%$, in the treatments of $75 \%, 50 \%$ and $25 \%$ of the "capacity of pot" (CP), respectively, in relation to seedlings maintained at $100 \%$ of CP. The differences between results, are certainly due to differences in the environment and age of seedlings in both surveys, because these authors assessed the DC to 155 days after germination.

Regardless of the irrigation blade and the container used, the DC of jatobazeiro, at 120 DAS, was higher than that found by Leles et al. (1998), also in the house of vegetation. The lower DC obtained by these authors should probably have evaluated this parameter in seedlings of lower age at $110 \mathrm{DAS}$ and in conditions of mild water deficit. At 200 DAS, the DC was consistent to the obtained by Carvalho Filho et al. (2003), to 180 DAS, in plastic bag of $15 \times 20 \mathrm{~cm}$.

The results of AF of this work are compatible with those of Nascimento et al. (2011), since that authors obtained AF of $758.6 \mathrm{~cm}^{2}$ seedling ${ }^{-1}$, to 155 days after germination, in water treatment of $100 \%$ of humidity in the "pot capacity" (CP). They still verified that the blade of $25 \%$ of CP reduced the AF in $70.1 \%$, in relation to the witness, while in this study, the mean reduction of AF in the blade of $20 \%$ to 200 DAS, was $85.7 \%$, in relation to the refitting of $100 \%$ of the ETp. According to Santos and Carlesso (1998), the reduction in AF is a prominent response of plants to water deficit. Significant reduction in AF was also observed in the agricultural crops, by Alves Junior et al. (2005), Paiva Sobrinho et al. (2011) and Ünlü et al. (2011), in plants of acid lime 'Tahiti', sunflower and cotton, respectively, when the fraction of water available in the soil was below the evapotranspirometric demand.

The MSM to 160 DAS, is superior than that obtained by Nascimento et al. (2011), in part due to differences in environments where the experiments were conducted. These authors obtained MSM $18.6 \mathrm{~g} \mathrm{seedlings}^{-1}$, in jatobazeiros with 155 days after germination, irrigated at $100 \%$ of $\theta_{\text {cc }}$, in vases with $8.0 \mathrm{~kg}$ of soil, while in this experiment containers were used with the smallest quantity of substrate but, probably of greater availability of nutrients. 
The higher relation MSR/MSPA, in seedlings o $H$. courbaril L. of higher age, is a mechanism of resistance to drought, also observed in other species, as Arachis hypogaea L. (Correia e Nogueira, 2004). To the extent that the seedlings are developed in a given volume of substrate, hydric demand becomes larger. For this reason, they are induced to develop the root system, for better access to water and, consequently is greater the absorption by radicelas.

\section{CONCLUSIONS}

1. Seedlings of $H$. courbaril developed better in citrovase than in vase, because of greater potential evapotranspiration that occurred in the first.

2. Irrigation blades of 90 to $100 \%$ of the ETp provide more vigorous seedlings of jatobazeiro.

3. The increase of the water deficit reduces all characteristics of jatobazeiro (AM, DC, AF e MSP), except the relationship MSR/ADM.

\section{REFERENCES}

ALVES JÚNIOR, J.; SILVA, C.R.; SILVA, T.J.A.; RIBEIRO, R.V.; FOLEGATTI, M.V. Crescimento de plantas jovens de limeira-ácida 'Tahiti' sob lâminas de irrigação. Engenharia Agrícola, v.25, n.1, p.170-178, 2005.

AZERÊDO, G.A.; BRUNO, R.L.A; ANDRADE, L. A.; CUNHA, A.O. Germinação em sementes de espécies florestais da Mata Atlântica (Leguminoseae) sob condições de casa de vegetação. Pesquisa Agropecuária Tropical, v.33, n.1, p.11-16, 2003.

CARVALHO FILHO, J.L.S.; ARRIGONI-BLANK, M. F.; BLANK, A.F.; RANGEL, M.S.A. Produção de mudas de jatobá (Hymenaea courbaril L.) em diferentes ambientes, recipientes e composições de substratos. Cerne, v.9, n.1, p.109-118, 2003.

CARVALHO, P.E.R. Espécies arbóreas

brasileiras. Brasília: Embrapa Informação Tecnológica; Colombo: Embrapa Florestas, 2003. v.1.

CORREIA, K.G.; NOGUEIRA, R.J.M.C. Avaliação do crescimento do amendoim (Arachis hypogaea L.) submetido a déficit hídrico. Revista de Biologia e Ciências da Terra, v.4, n.2, p.1-7, 2004.

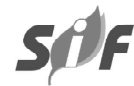

FERRAZ, A.V.; ENGEL, V.L. Efeito do tamanho de tubetes na qualidade de mudas de jatobá (Hymenaea courbaril L. var. stilbocarpa (Hayne) Lee et Lang.), ipê-amarelo (Tabebuia chrysotricha (Mart. ex DC.) Sandl.) e guarucaia (Parapiptadenia rigida (Benth.) Brenan.

Revista Árvore, v.35, n.3, p.413-423, 2011.

FIGUEIRÔA, J.M.; BARBOSA, D.C.A.; SIMABUKURO, E.A. Crescimento de plantas jovens de Myracrodruon urundeuva Allemão (Anacardiaceae) sob diferentes regimes hídricos Acta Botânica Brasílica, v. 18, n.3, p.573580, 2004.

GONDIM, T.M.S.; SILVA, F.F.S.; FERNANDES, P.D.; BELTRÃO, E.M.; SILVA FILHO, J.L. Teor relativo de água e métodos para determinação de área foliar em algodão colorido Gossypium hirsutum cultivar BRS 200 marrom. In: CONGRESSO BRASILEIRO DO ALGODÃO, 7., 2009, Foz do Iguaçu. Anais... Campina grande: Embrapa Algodão, 2009. p. 941-951.

LEE, Y.T.; LANGENHEIM, J.H. Systematics of the genus Hymenaea L. (Leguminosae, Caesalpinioidea, Detarieae). Berkeley: University of California Press, 1975. 105p.

LELES, P.S.S.; CARNEIRO, J.G.A.; BARROSO, D.G. Comportamento de mudas de Hymenaea courbaril L. var stilbocarpa (Hayne) e Apuleia leiocarpa (Vog.) Macbr. produzidas sob três regimes de irrigação. Revista Árvore, v.22, n.1, p.11-19, 1998.

LOPES, J. L.W.; GUERRINI, I.A.; SAAD, J.C.C.; SILVA, M.R. Efeitos na irrigação na sobrevivência, transpiração e no teor relativo de água na folha em mudas de Eucalyptus grandis em diferentes substra-tos. Scientia Forestalis, n.68, p.97$106,2005$.

NASCIMENTO, H.H.C. Caracterização ecofisiológica de mudas de jatobá (Hymenaea courbaril L.) submetidas a déficit hídrico. 2009. 90f. Dissertação (Mestrado em Ciências Florestais) - Universidade Federal Rural de Pernambuco, Recife, 2009.

NASCIMENTO, H.H.C.; NOGUEIRA, R.J.M.C.; SILVA, E.C.; SILVA, M.A. Análise do crescimento de mudas de jatobá (Hymenaea courbaril L.) em

Revista Árvore, Viçosa-MG, v.40, n.3, p.487-498, 2016 
diferentes níveis de água no solo. Revista Árvore, v.35, n.3, p.617-626, 2011.

NEVES, C.S.V.J.; MEDINA, C.C.; AZEVEDO, M.C.B.; HIGA, A.R.; SIMON, A. Efeitos de substratos e recipientes utilizados na produção de mudas sobre a arquitetura do sistema radicular de árvores de acácia negra. Revista Árvore, v.29, n.6, p.897-905, 2005.

OLIVEIRA, P.K.B.; OLIVEIRA, T.S.; CAMELO, A.M.; ROMERO, R.E. Crescimento de plantas de cajueiro anão precoce influenciado pela compactação e temperatura do solo. Revista Brasileira de Ciência do Solo, v.27, n.1, p.11-18, 2003.

PACHECO, A.R. Adubação de mudas de baru (Dipteryx alata Vog.), em viveiro. 2008. 86f. Tese (Doutorado em Produção Vegetal) - Escola de Agronomia e Engenharia de Alimentos, Universidade Federal de Goiás, Goiânia, 2008.

PAIVA SOBRINHO, S.; TIEPPO, R.C.; SILVA, T.J.A. Desenvolvimento inicial de plantas de girassol em condições de estresse hídrico. Enciclopédia Biosfera, v.7, n.12, p.1-12, 2011.
PEREIRA, M.R.R.; KLAR, A.E.; SILVA, M.R.; SOUZA, R.A.; FONSECA, N.R. Comportamento fisiológico e morfológico de clones de Eucalyptus urograndis submetidos a diferentes níveis de água no solo. Irriga, v. 11, n.4, p.518-531, 2006.

SAMÔR, O.J.M.; CARNEIRO, J.G.A.; BARROSO, D.G.; LELES, P.S.S. Qualidade de mudas de angico e sesbânia, produzidas em diferentes recipientes e substratos. Revista Árvore, v.26, n.2, p.209$215,2002$.

SANTOS, R.F.; CARLESSO, R. Déficit hídrico e os processos morfológico e fisiológico das plantas. Revista Brasileira de Engenharia Agrícola e Ambiental, v.2, n.3, p.287-294, 1998

SILVA, M.R.; SILVA, M.S.; MARTINS, K.A.; BORGES, S. Utilização tecnológica dos frutos de jatobá-do-cerrado e de jatobá-da-mata na elaboração de biscoitos fontes de fibra alimentar e isentos de açúcares. Ciência e Tecnologia de Alimentos, v.21, n.2, p.176-182, 2001.

ÜNLÜ, M.; KANBER, R.; KOÇ, D.L.; TEKIN, S.; KAPUR, B. Effects of deficit irrigation on the yield and yield components of drip irrigated cotton in a mediterranean environment.

Agricultural Water Management, v.98, n.4, p.597-605, 2011. 